
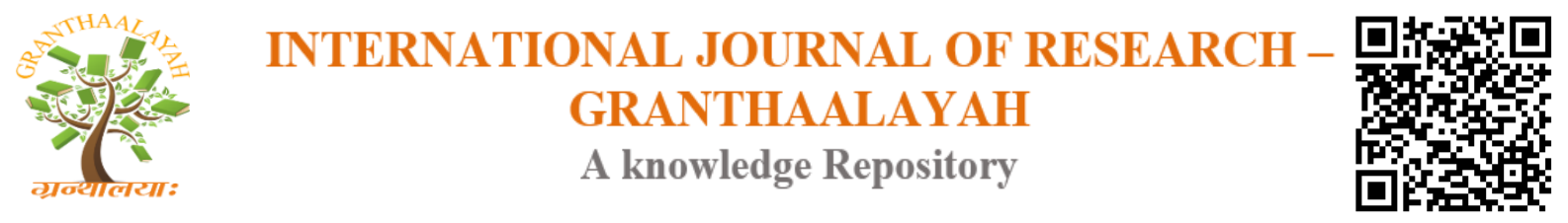

Management

\title{
AGE DIVERSITY IN THE WORKPLACE: A STUDY ON PRIVATE SECTOR BANKS EMPLOYEES
}

\author{
Ritesh Kumar ${ }^{* 1}$, Prof. Rajpal Singh ${ }^{2}$ \\ ${ }^{* 1}$ Assistant Professor, Govt. College for Women, Salaheri (Nuh), India \\ ${ }^{2}$ Professor, Department of Commerce, Maharshi Dayanand University, Rohtak, India
}

\begin{abstract}
Diversity plays a vital role in the success of business if it is managed properly. Age diversity is the heterogeneity in the organization in term of age. In every organization, there is a conflict between the mindset of generations. Conservative and modern thinking in organization cause resistance of decisions. Although both experienced and young employees were fruitful for the organization if they were properly managed. This paper primarily investigates how the age diversity affects the performance of private bank employees. Under the present study, 100 employees of different private sector banks branches located in Rohtak city were sorted out on the basis of convenience sampling technique. A self-structured questionnaire was used to acquire data from respondents. Different statistical tools such as descriptive, correlation were used in this study to test the hypothesis. Results revealed that there is a moderately positive relationship between age diversity and employees performance.
\end{abstract}

Keywords: Diversity; Age; Performance; Heterogeneity.

Cite This Article: Ritesh Kumar, and Prof. Rajpal Singh. (2017). "AGE DIVERSITY IN THE WORKPLACE: A STUDY ON PRIVATE SECTOR BANKS EMPLOYEES.” International Journal of Research - Granthaalayah, 5(8), 120-126. 10.29121/granthaalayah.v5.18.2017.2196.

\section{Introduction}

Increased globalization in workplaces leads to the more diversified workforce in an organization. A more diversified organization will be advantageous for the organization. In past days globalization has been changed not only within the country but crossed the limits. Globalization caused a benevolent workforce movement. For multicultural organizations, it's necessary to deal with workers from various cultures and backgrounds. The multicultural workforce strengthens HR managers to face new challenges, due to changes in management practices. The propensity to improve the diversity and heterogeneity of the organization is rewarding only when handling effectively. The term "diversity" was not widely used to describe labour force characteristics until the mid-1980s after a widely disseminated report attracted much attention in the corporate argued that "demography is fate" and claimed that dramatic changes were taking place in the labour force. The major principles underpinning this approach to management and explain the 
difference between affirmative actions and diversity practices. Age diversity is the calibre of a company to concede all different types of ages within an organization. It is the heterogeneity in the workforce in term of age. Various organizations have to manage the composition of different ages in various ways. On the one hand, companies will encounter with an aging workforce while on the other hand, manage a beneficial composition of the workforce. Thus, they will have to make profitable use of the skills of older employees as well as the enthusiasm of young employees. The banking sector in India has been governed by public banks since 1969 when 19 banks were nationalized by the Indian government. However, since liberalization, various private sector banks emerged in Indian economy. They have evolved quicker and bigger over last the two decades since liberalization using the upgraded technology, providing periodic innovations. There are 26 private sector banks presently operating in India. Private-sector banks are those banks where more than 50\% parts of share or equity are held by the private share holders. This paper primarily focuses on the impact of age diversity on the performance of private banks employees.

\section{Review of Literature}

Review of literature is a precious part of any research work which guides us in the right direction. We have collected information from related researches and similar studies conducted in the field of age diversity so that the important variables for the study could be recognized and analyzed.

Patrick and Kumar (2012) conducted a research on the topic, "Managing Workplace Diversity: Issues and Challenges". The study highlighted that diversity management is a process designed to build and maintain a positive work environment where similarities and dissimilarities between individuals are assessed. Further researchers explain workforce diversity as a variety of characteristics between people in an organization.

Gellner and Veen (2013) under their research entitled, "Positive Effects of Ageing and Age Diversity in Innovative Companies -Large Scale Evidence on Company Productivity" studied that how heterogeneity in age within an organization influence the productivity. The result of the study indicates that age diversity has positively influenced the company's productivity only if company participates in brainstorming tasks or decision problems rather than routine work.

Bedi et al. (2014) under their research entitled, "Workforce Diversity Management: Biggest challenge or opportunity for $21^{\text {st }}$-century Organisation" explains workforce diversity as a threat and at the same time the biggest opportunity for modern managers. The prime objective of this study is to find out that how organizations handle heterogeneity in the workforce and its outcomes to the organization's existence as well as assess how organizations deal with challenges that come with employees from different backgrounds. In the end, researchers conclude that the creation of a diverse workforce takes time and even longer to take advantage of benefits, and management must not lose focus and interest in building and maintaining a divergent workforce because of lack of immediate returns.

Rizwan et al. (2016) in their research entitled, "The Impact of Workforce Diversity towards Employee Performance: Evidence from Banking Sector of Pakistan”, investigate the influence of 
diversity on performance of employee working in the banking industry of Pakistan. According to the researchers, there are different factors that can affect the performance of the employee but this study includes only the most crucial variables among all the others. A sample of 230 employees was sorted out by the researcher. The finding of that study reveals that gender, ethnicity and educational background has a positive impact on the performance of employees while age diversity shows a negative effect on performance.

\section{Objective of the Study}

The objective of this study is to access the relationship between age diversity and performance of employees working in private sector branches of Rohtak city. Further, this study aims at the perception of private sector employees working in different branches of Rohtak city toward age diversity.

\section{Research Methodology}

In the current study, mainly descriptive research design had been adopted, as the main purpose of the study is to identify the relationship between age diversity and employee's performance. All employees working in the private sector banks branches of Rohtak city was the target population. Out of the total population, a sample of 100 employees was sorted out using convenience sampling technique. A self-administered questionnaire was used to acquire the data from employees.

\section{Scope of the Study}

The main objective of this research is to analyze the impact of age diversity on employee performance in Private sector banks of Rohtak City. This study focuses on the employees currently working in the private bank's branches located in Rohtak city. There were 26 private banks branches of 10 private sector banks operating in Rohtak. Out of these 26 private bank branches, employees of 10 branches of IDBI, ICICI, IndusInd, Axis Bank, Federal Bank, HDFC bank and Kotak Mahindra Bank were taken as a sample. Under the present study, a sample of 100 employees working in private banks drawn out of the population. Non-probability sampling technique was used in this study.

\section{Hypotheses of the Study}

In this study, employee performance is our response variables. Meanwhile, age will be our predictor variables.

$\mathrm{H}_{0}$ : There is no significant relationship between age diversity and employee performance.

$\mathrm{H}_{1}$ : There is a significant relationship between age diversity and employee performance.

\section{Results and Discussions}

This section represents the statistical analysis of the data and interpretation of the results. The statistical techniques adopted are charts, descriptive analysis, and Pearson's correlation. SPSS, version 21, the statistical software has been used to obtain the results. 


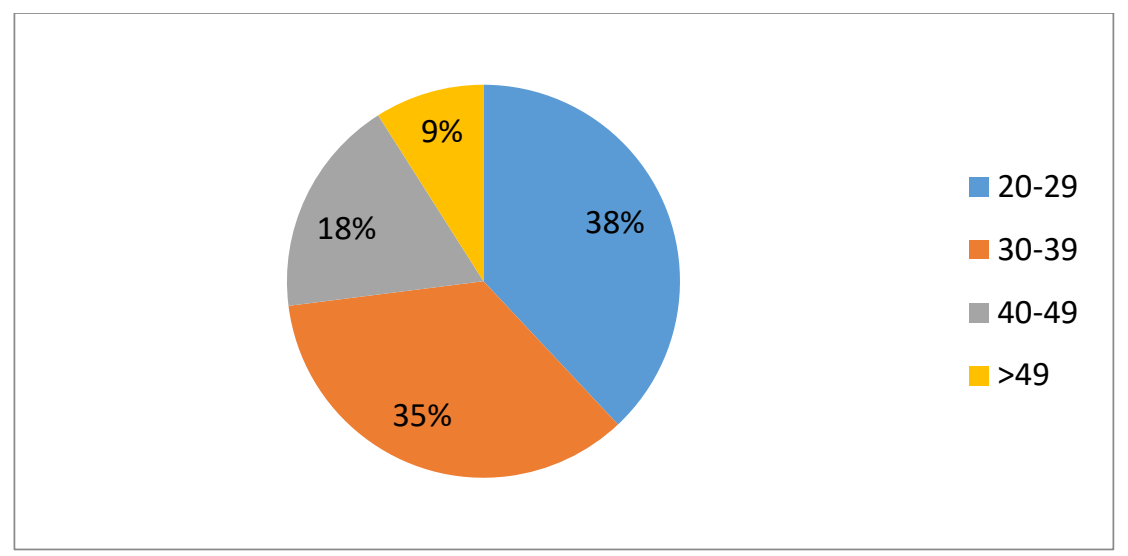

Figure 1: Age Composition in Private Sector Banks

Source: Primary Data

Figure 1 shows age composition of the respondents from private sector banks branches located in Rohtak city. The majority of the respondents fall under the age group category of 20 - 29 years old (accounted for $38 \%$ or 38 respondents), followed by the age group of $30-39$ years old (35\% or 35 respondents), 40 - 49 years old (18\% or 18 respondents), and above 49 years old (9\% or 9 respondents).

\section{Perception toward Age Diversity}

Measurement of central tendencies is used to discover the perception of respondents towards age diversity in the banking sector.

Table 1: Central Tendencies Measurement of Age Diversity

\begin{tabular}{|l|l|l|l|}
\hline Particulars & $\mathbf{N}$ & Mean & Standard deviation \\
\hline $\begin{array}{l}\text { Equal opportunities for training and development for all } \\
\text { age group employees in this bank }\end{array}$ & 100 & 3.15 & 1.095 \\
\hline $\begin{array}{l}\text { Different age groups are inviting to participate in } \\
\text { problem solving and decision making by the manager. }\end{array}$ & 100 & 3.38 & .862 \\
\hline $\begin{array}{l}\text { Heterogeneity in term of age in the bank might cause } \\
\text { dispute. }\end{array}$ & 100 & 2.99 & 1.040 \\
\hline $\begin{array}{l}\text { At work, there is a gap in mindset between young and } \\
\text { old employees. }\end{array}$ & 100 & 3.07 & 1.047 \\
\hline I enjoy age diversity in this bank. & 100 & 3.67 & .829 \\
\hline
\end{tabular}

From the above table we can observe that the mean was high for the statement stating that employees are positive towards age diversity in the bank with mean value of 3.67 and standard deviation of .829 and different age groups are inviting to participate in problem solving and decision making by the manager with mean value of 3.38 and standard deviation of .862 . So from these two statements, we conclude that perception of employees of private sector banks toward age diversity is positive. Although the statement "heterogeneity in term of age in the bank might cause dispute" with the mean value of 2.99 and standard deviation of 1.040 which depicts that higher the difference between age group in banks might cause the dispute between them so it should be managed properly. 
Table 2: Central Tendencies Measurement of Employees Performance

\begin{tabular}{|l|l|l|l|}
\hline Particulars & N & Mean & Standard deviation \\
\hline $\begin{array}{l}\text { Most important duties and responsibilities are assigned } \\
\text { to old age employees. }\end{array}$ & 100 & 3.79 & .743 \\
\hline $\begin{array}{l}\text { My colleagues of different age group motivated and } \\
\text { helped me to complete the task. }\end{array}$ & 100 & 3.83 & .829 \\
\hline $\begin{array}{l}\text { Employees with different age group perform well and I } \\
\text { enjoy work with them. }\end{array}$ & 100 & 3.91 & .740 \\
\hline $\begin{array}{l}\text { Irrespective of my age, my performance level affects my } \\
\text { salary level. }\end{array}$ & 100 & 3.89 & .942 \\
\hline $\begin{array}{l}\text { This bank organizes various T\&D programs for all age } \\
\text { group, so I can improve my task performance. }\end{array}$ & 100 & 3.80 & 1.231 \\
\hline $\begin{array}{l}\text { Good employee performance is important for the future } \\
\text { growth of my bank. }\end{array}$ & 100 & 4.12 & .518 \\
\hline
\end{tabular}

From the above table, we can observe that the mean was high for the statement stating good employee performance is important for the future growth of my bank with mean value of 4.12 and standard deviation of .518 which indicates that bank should organise various T\&D programmes which help them to improve their individual as well as bank performance. "Most important duties and responsibilities are assigned to old age employees" with the mean value of 3.79 and standard deviation of .743 having the least mean score and it implies that bank should assign their important assignments to young employees too.

Table: 3 Pearson's Correlation Coefficient

\begin{tabular}{|l|l|l|l|}
\hline \multirow{2}{*}{ Age } & & Age & Employee Performance \\
\hline \multirow{3}{*}{ Employee Performance } & Pearson Correlation & 1 & $.490^{* *}$ \\
\cline { 2 - 4 } & Sig. (2-tailed) & & .000 \\
\hline & $\mathrm{N}$ & 100 & 100 \\
\cline { 2 - 4 } & Pearson Correlation & $.490^{* *}$ & 1 \\
\cline { 2 - 4 } & Sig. (2-tailed) & .000 & \\
\cline { 2 - 4 } & $\mathrm{N}$ & 100 & 100 \\
\hline
\end{tabular}

**. Correlation is significant at the 0.01 level (2-tailed)

\section{Interpretation}

Above table indicates that there is a positive relationship between age diversity and employee performance. The age group variable has a .490 correlation with the employee performance. Further, the above table shows that the value of correlation coefficient (.490) falls under coefficient range from \pm .41 to \pm .60 . Hence, there is a moderately positive relationship between age and employee performance.

\section{Hypothesis Testing}

The p-value of the correlation coefficient is .000 which is less than 0.01 . Therefore, alternative hypothesis $\left(\mathrm{H}_{1}\right)$ is accepted and the null hypothesis $\left(\mathrm{H}_{0}\right)$ is not accepted. Hence, we conclude that there is a relationship between age diversity and employees performance. 


\section{Findings of the Study}

The main objective of this study was to describe the influence of age diversity on employees' performance. 100 employees have been taken from private sector banks branches located in Rohtak city. The workplace of private banks constitutes the heterogeneous mix of employees from the different caste, religion, sex, marital status. More and more young employees are also entering into the banking sector and there is a need for proper diversity management strategies. It is observed from the research that there are different types of obstacles present in the banking sector which have the impact on the acceptance of diversity among employees. Based on the result from preceded section, there is a moderately positive relationship between age diversity and employee performance which carries correlation coefficient value of .490 and p-value of .000 which is less than from the alpha value 0.01 . The finding in this research showed that age and employee performance is positively linked.

\section{Conclusion}

The conclusion of the study is there a positive relationship between age diversity and performance of employees of private sector banks branches located in Rohtak city. The correlation coefficient for age and employee performance is .490 which indicates that there is a moderately positive relationship between age diversity and employee performance. So it became important for private banks to must maintain the diversity to gain the competitive advantages. There are some other variables too which affect the performance of employees as well as banks. Although the study showed that age diversity shows positive relationship which means that employees feel comfortable working with different age group which also affect their performance. In the end conclude that, in the era of globalization, the bank should maintain diversity and also frame some policy related to diversity management so that productivity and performance both will be enhanced. Since the diversity is becoming one of the most popular ways to ascertain the employee performance in companies in the recent year, the research tends to provide the evidence to support future research related to this field.

\section{References}

[1] Aswathappa, K. (2006). Human Resource and Personnel Management, 4th edition, Tata McGraw-Hill, New Delhi.

[2] Bedi, P., lakra, P., \& Gupta, E. (2014). Workforce Diversity Management: Biggest Challenge Or Opportunity For 21st Century Organizations. Journal of Business and Management, 16 (4), 102107.

[3] Gellner, U. B., \& Veen, S. (2009). The Impact of Aging and Age Diversity on Company Performance. SSRN Electronic Journal, 1-34.

[4] Kamal, Y., \& Ferdousi, M. M. (2009). Managing Diversity at Workplace: A Case Study of HP. ASA University Review, 3 (2), 157-170.

[5] Kunze, F., Boehm, S. A., \& Bruch, H. (2011). Age diversity, age discrimination climate and performance consequences - a cross organizational study. Journal of Organizational Behavior, 32 (2), 264-290.

[6] Owoyemi, O. A., Elegbede, T., \& Gbajumo-Sheriff, M. (2011). Age Diversity and the Future of Workforce in Nigeria. European Journal of Economics, Finance and Administrative Sciences (30), 65-75. 
[7] Patrick, H. A., \& Kumar, V. R. (2012). Managing Workplace Diversity: Issues and Challenges. SAGE Open, 1-15.

[8] Rizwan, M., Khan, M. N., Nadeem, B., \& Abbas, Q. E. (2016). The Impact of Workforce Diversity Towards Employee Performance: Evidence from Banking Sector of Pakistan. American Journal of Marketing Research, 2 (2), 53-60.

[9] Soni, V. (2000). A Twenty-First Century Reception for Diversity in the Public Sector: A case study. Public Administration Review, 60 (5), 395-408.

[10] Williams, K. Y., \& O'Reilly, C. A. (1998). Demography and Diversity in Organisations: A Review 40 Years of Research. Research in Organisation Behaviour, 20, 77-140.

[11] Woodard, N., \& Saini, D. S. (2006). Diversity Management Issue in USA and India: Some Emerging Perspective. Future of Work: Mastering Change, 149-164.

*Corresponding author.

E-mail address: rik.chhonkar007@ gmail.com 